KEITH BAUER, SARA TAUB and KAYHAN PARSI

\title{
ETHICAL ISSUES IN TISSUE BANKING FOR RESEARCH: A BRIEF REVIEW OF EXISTING ORGANIZATIONAL POLICIES
}

\begin{abstract}
Based on a general review of international, representative tissue banking policies that were described in the medical, ethics, and legal literature, this paper reviews the range of standards, both conceptually and in existing regulations, relevant to four main factors: (1) commercialization, (2) confidentiality, (3) informed consent, and (4) quality of research. These four factors were selected as reflective of some of the major ethical considerations that arise in the conduct of tissue banking research. The authors emphasize that any policy or ethical guidelines designed to regulate tissue bank research should address all four factors. Whenever this sort of research is conducted between several institutions or several countries, the paper suggests that the relevant entities work collaboratively to harmonize their standards.
\end{abstract}

KEY WORDS: commercialization, confidentiality, human tissue sample, informed consent, organizational policies, quality, research, standards, tissue banking

\section{INTRODUCTION}

Tissue banking research increasingly is conducted in partnership between the for-profit and not-for-profit spheres, raising many ethical considerations. ${ }^{1}$ In part, this change can be attributed to the growing sophistication of genomic technology and, in particular, the new interest it has fueled in human tissue. ${ }^{2}$ In fact, newly established tissue banks are surfacing - many of them private, for-profit enterprises that compete with non-profit tissue banks for the recovery and processing of these tissues. ${ }^{3}$ In addition, tissue banks in the non-profit sector are often supported by the pharmaceutical and biotech industries that help fund academic research and rely on human biological samples recovered and banked by these institutions. ${ }^{4}$ Some contend that the current system of safeguards (at least in the US) will become increasingly obsolete in protecting tissue donors; others point to a variety of cultural, organizational, and professional issues that question the ethical appropriateness of for-profit tissue banks and 
academic-industry relationships. ${ }^{5}$ In response to these concerns, various governments, non-governmental organizations, and other institutions have been drafting and promulgating policies to regulate tissue banks and their relationships with industry. These policies represent the consensus of private associations (such as the American Association of Tissue Banks), reflect the national policies of certain governments (such as Spain), and are the products of various international bodies (such as the European Union). Thus, these policies are broad in scope; we have not surveyed the institutional policies of individual banks, academic medical centers, or other institutions. Moreover, the enforcement mechanisms will similarly reflect the authority of the bodies that produce such policies. For instance, a private association will have relatively little authority to sanction individual banks for violations of certain policies; on the other hand, governments will have appropriate enforcement mechanisms to ensure compliance (although resources to achieve such compliance will vary from country to country).

Based on a general survey of representative tissue banking policies that were described in the medical, ethics, and legal literature, this paper reviews the range of standards, both conceptually and in existing regulations, relevant to four main factors: (1) commercialization, (2) confidentiality, (3) informed consent, and (4) quality of research (see Table 1). These four factors were selected as reflective of some of the major ethical considerations that arise in the conduct of tissue banking research. ${ }^{6}$ We recommend that any policy or ethical guidelines designed to regulate tissue bank research should address all four factors. Where this sort of research is conducted between several institutions or several countries, we suggest that the relevant entities work collaboratively to harmonize their standards.

\section{COMMERCIALIZATION OF HUMAN TISSUES}

A number of potential benefits stem from the commercialization of human tissues. For industry, the likelihood of profit based on medical products derived from human tissues is an effective incentive to invest in related academic research. With the judicious use of patents and other forms of intellectual property rights, industry has added reason to support cutting-edge and sometimes financially risky academic research involving human tissues. From the perspective of academic centers, the infusion of capital by industry can help to fund innovative 


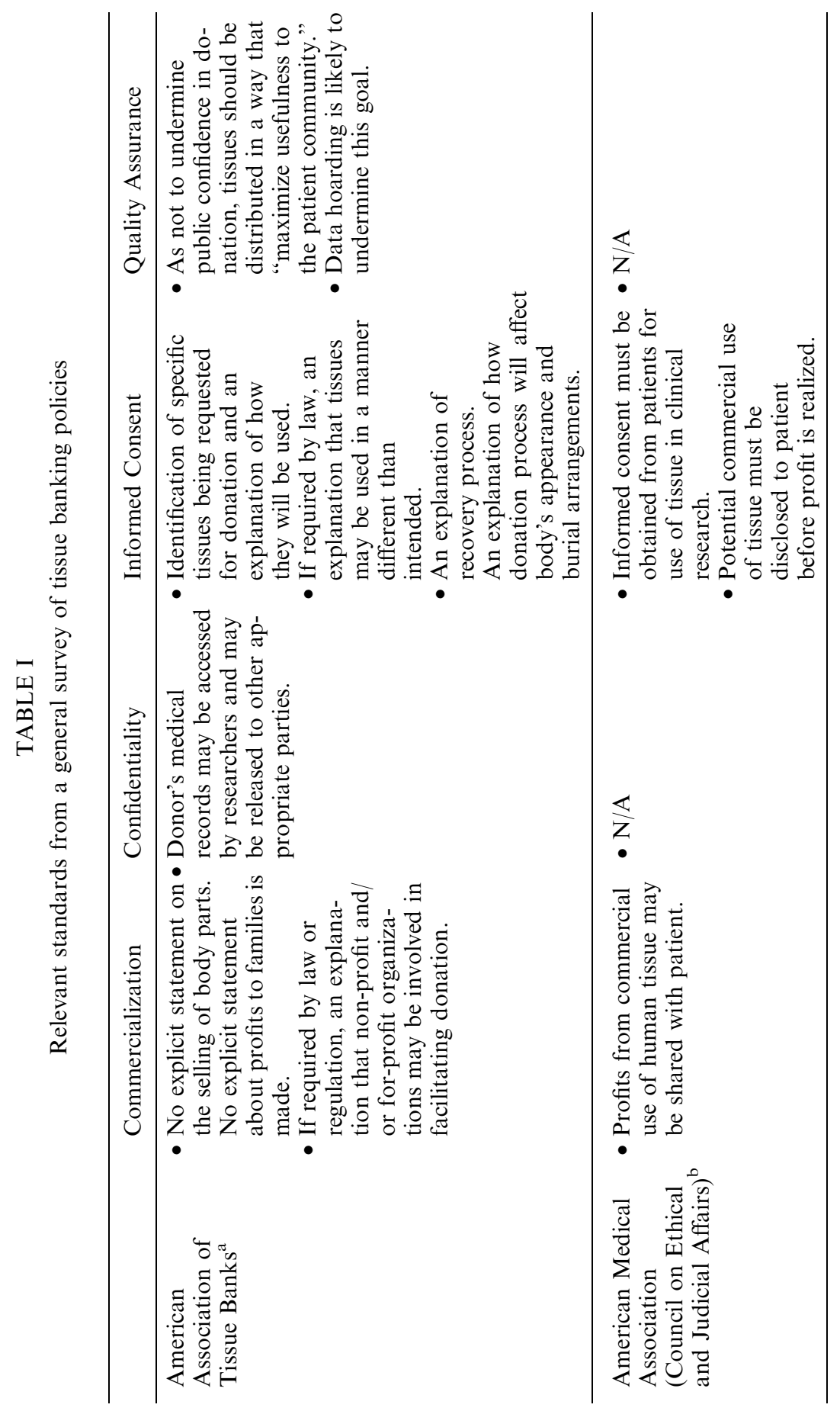




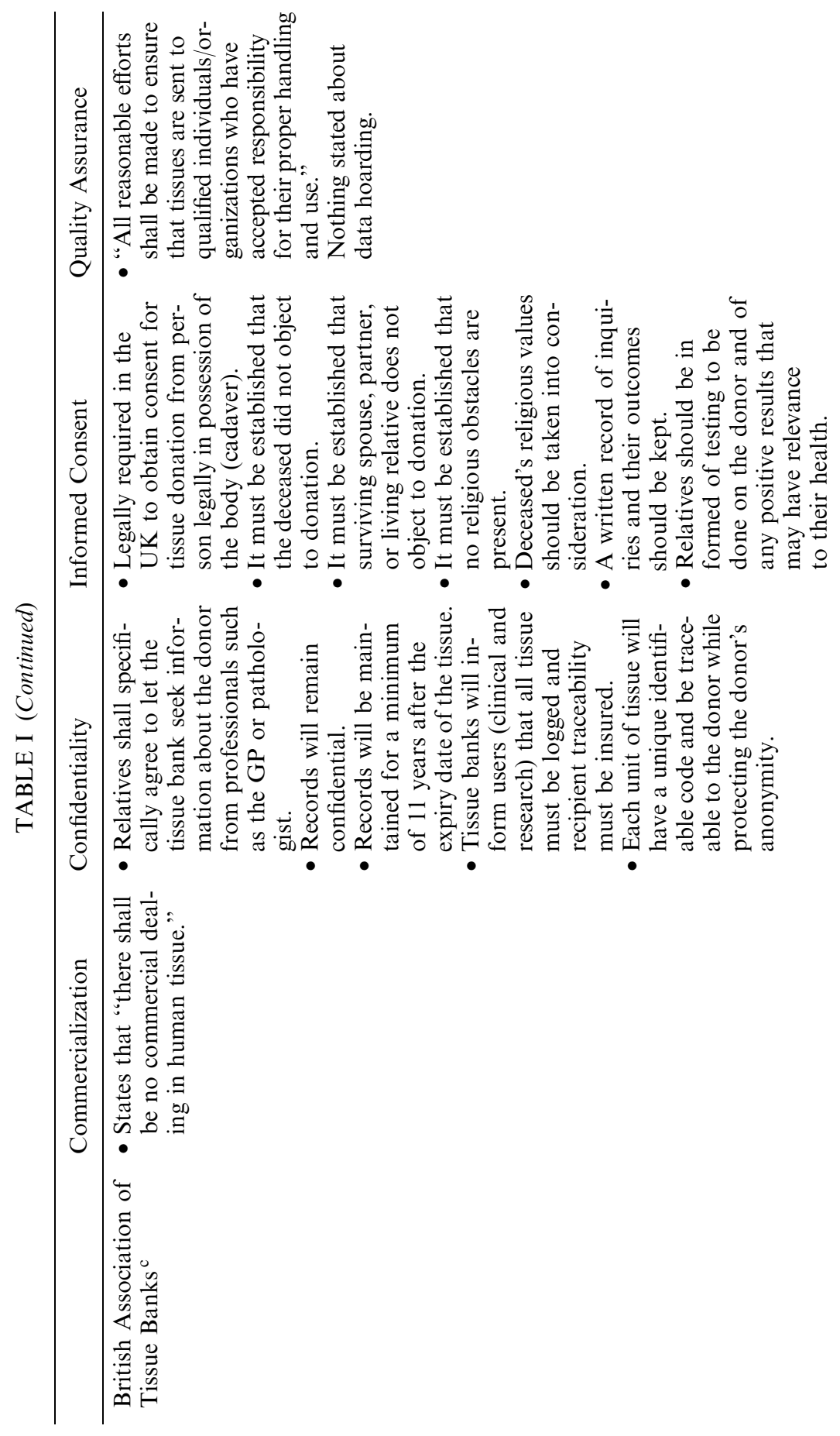




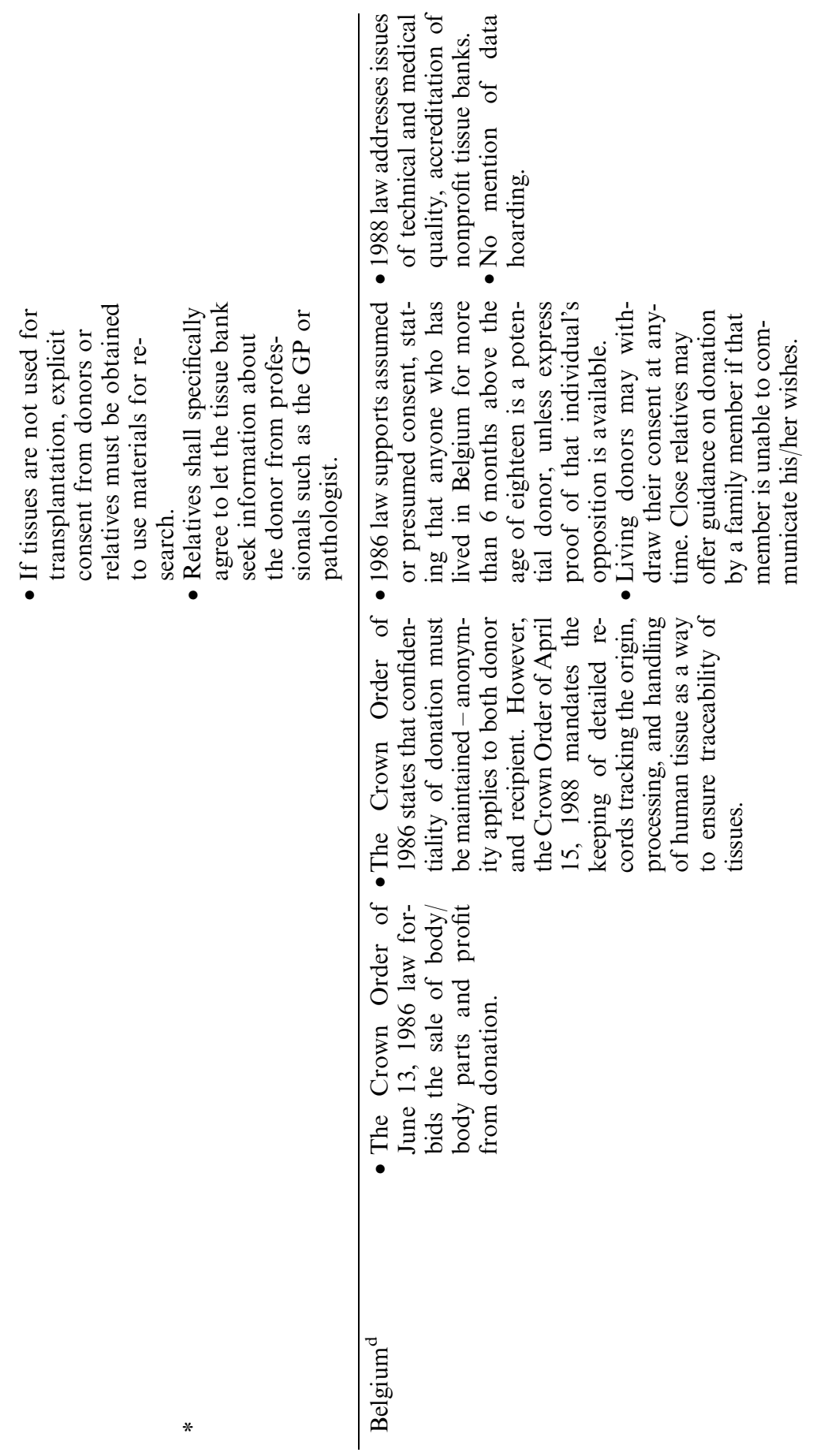




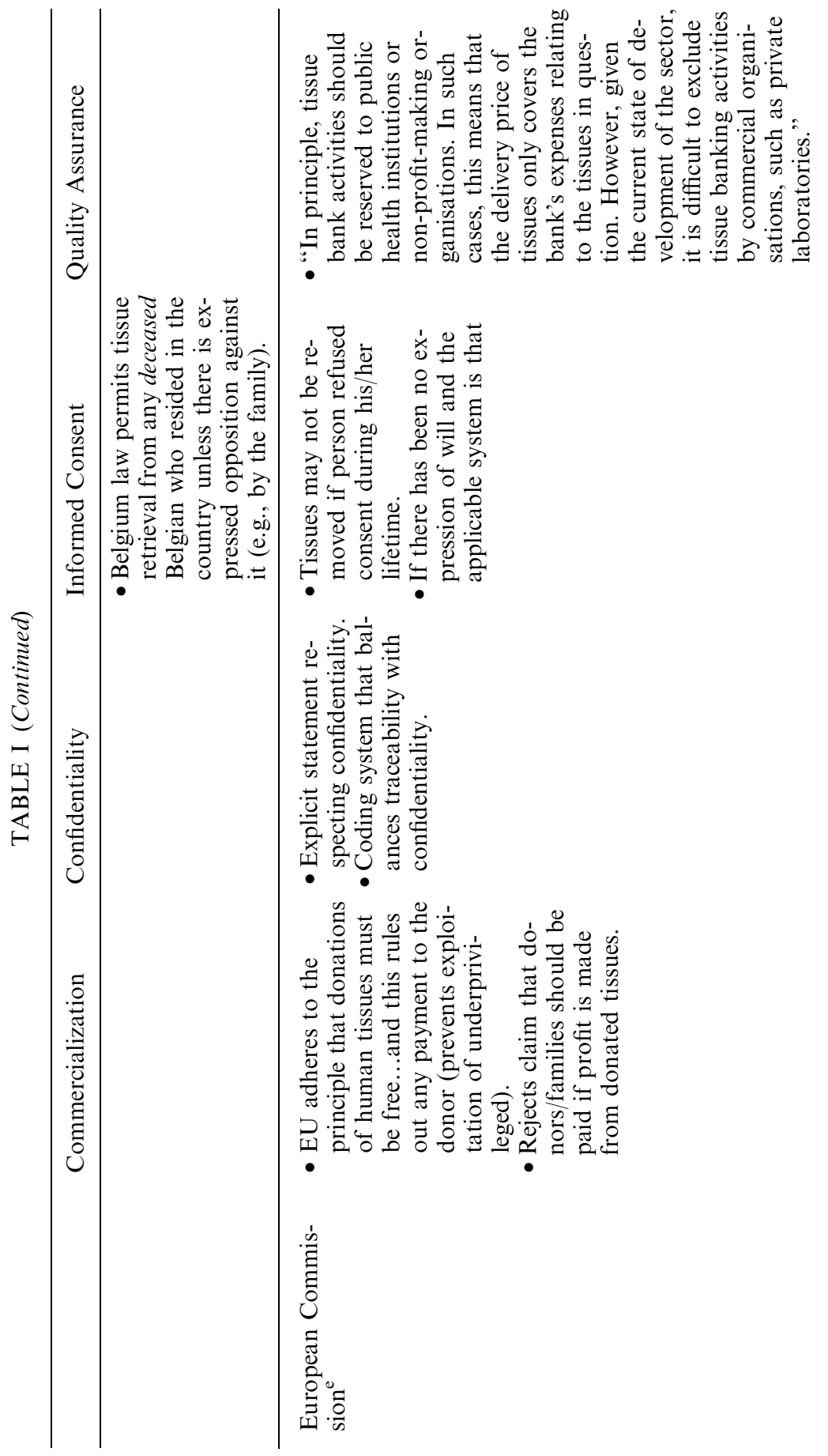




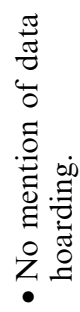

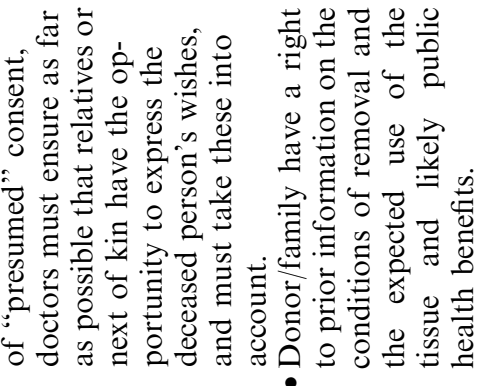

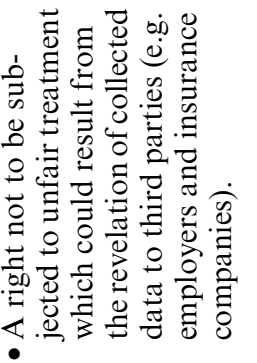

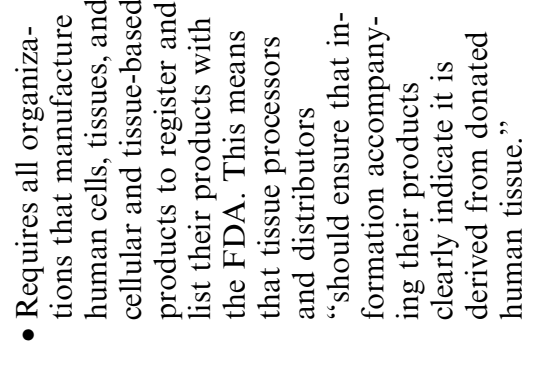
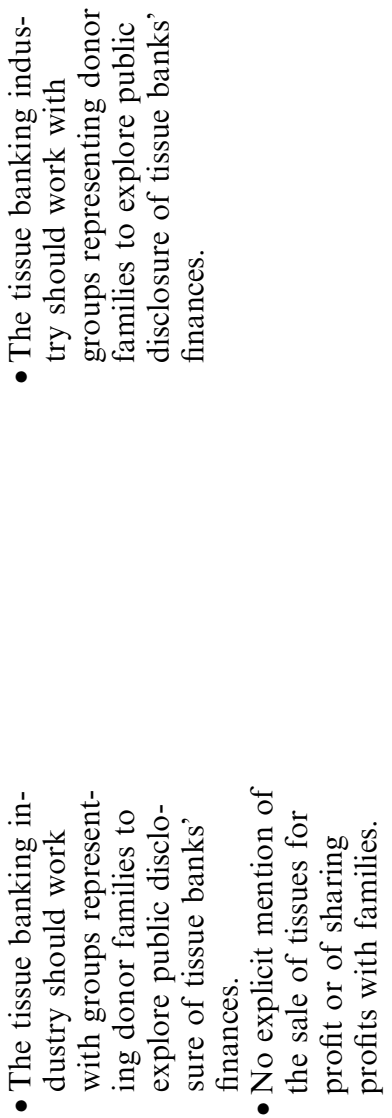

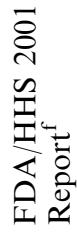




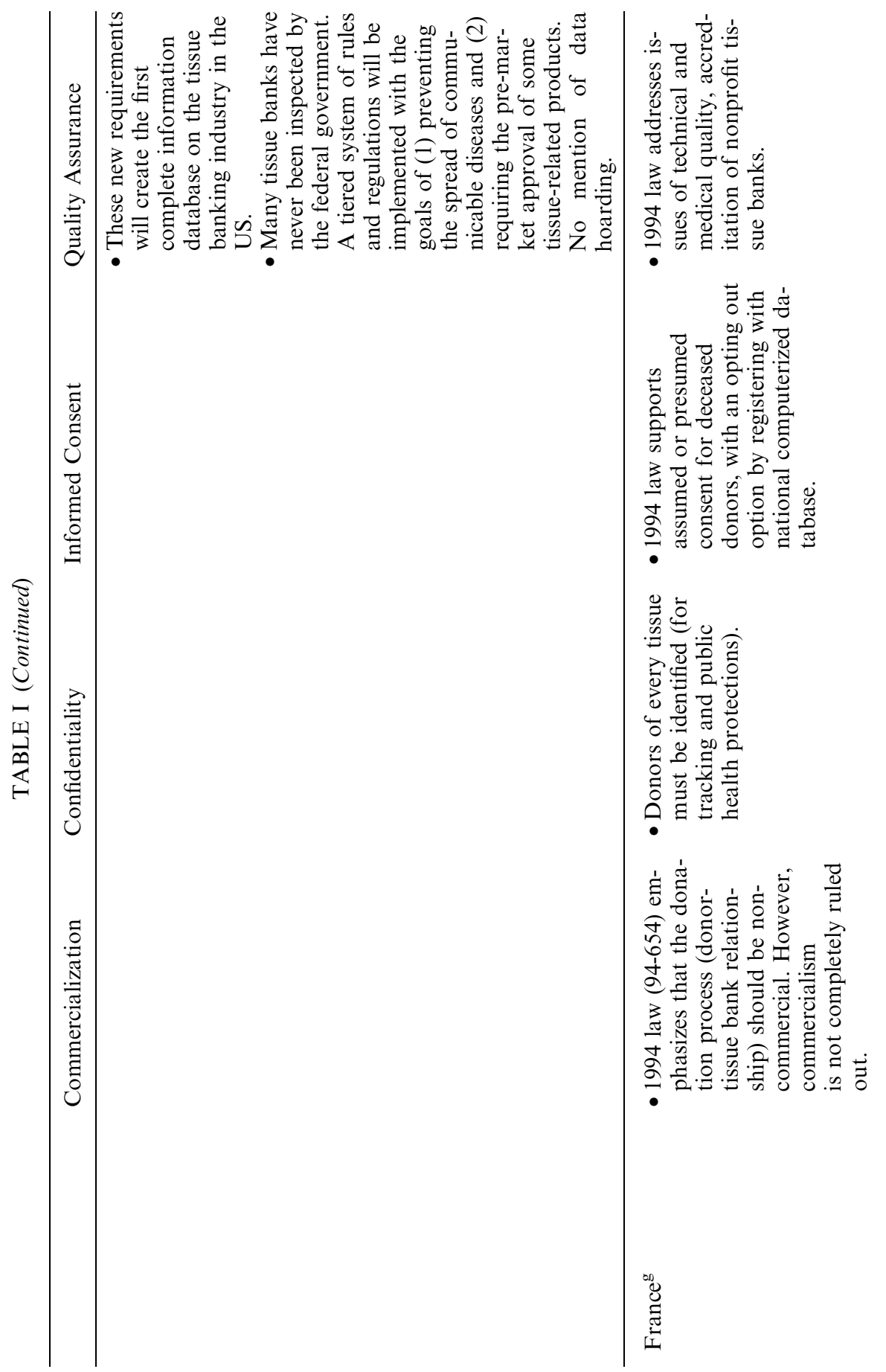



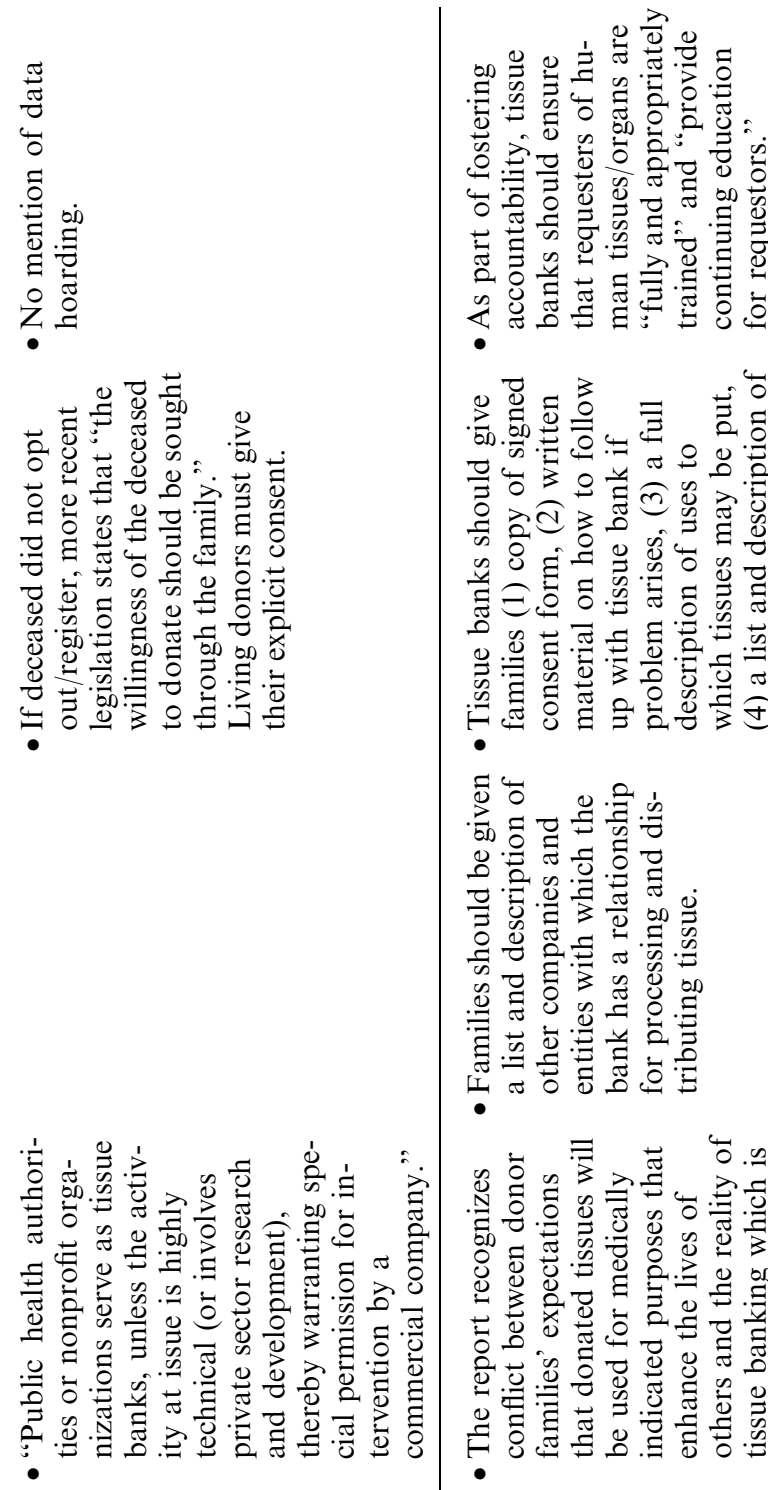

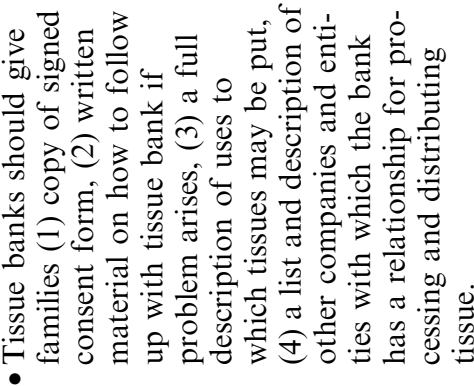

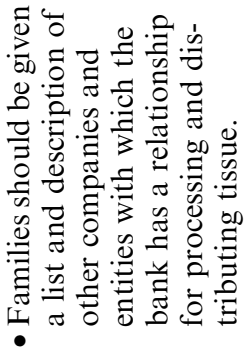

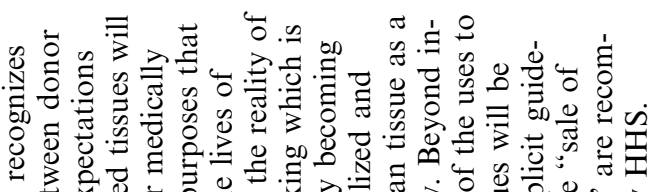

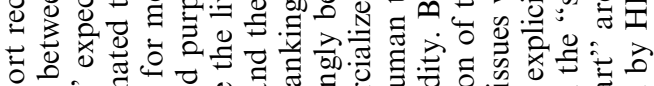

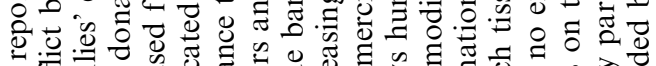

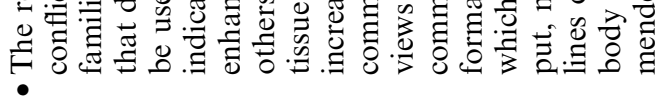

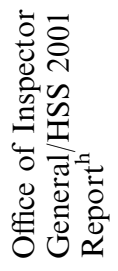




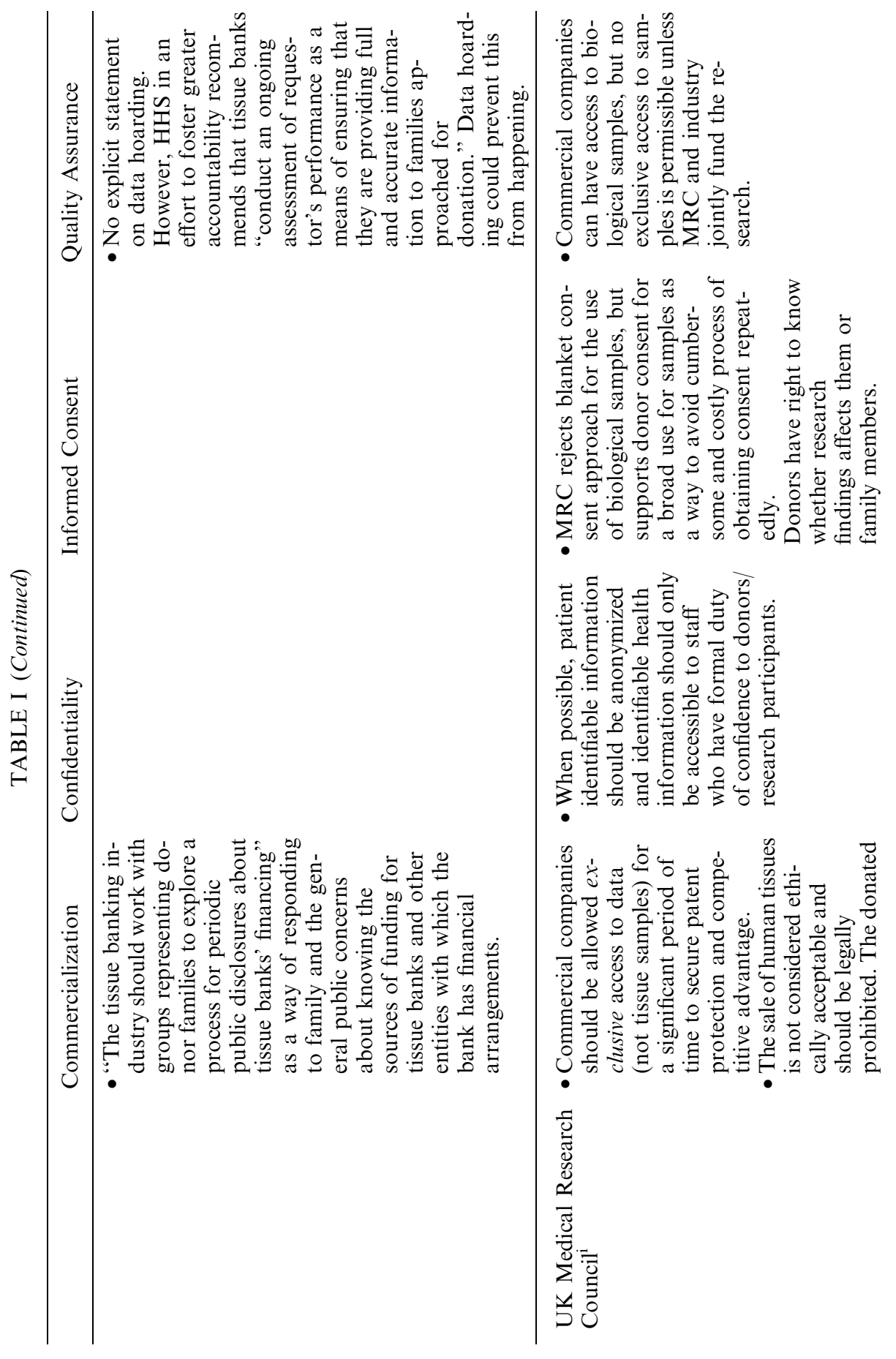



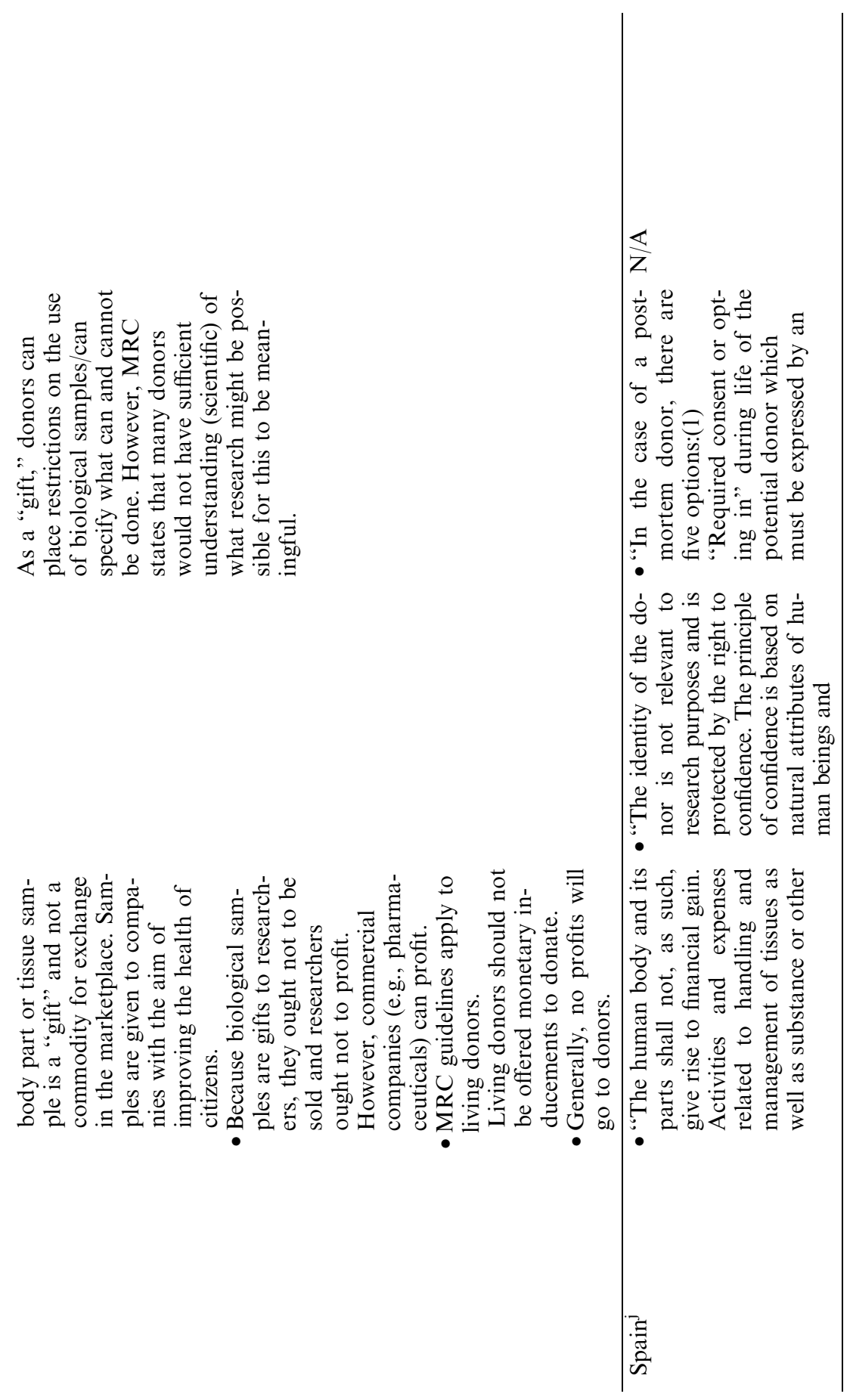

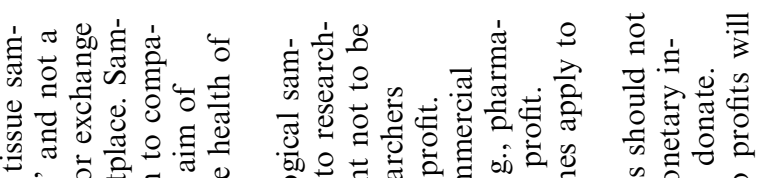

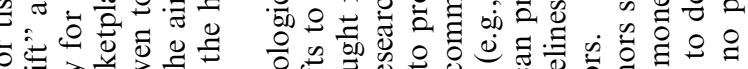

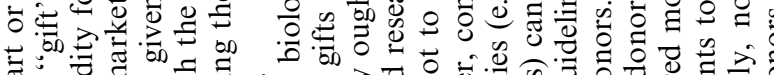

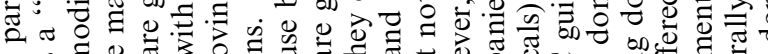

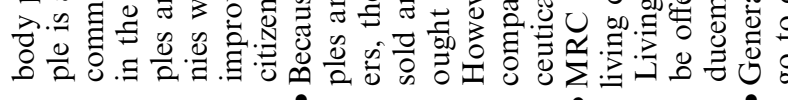




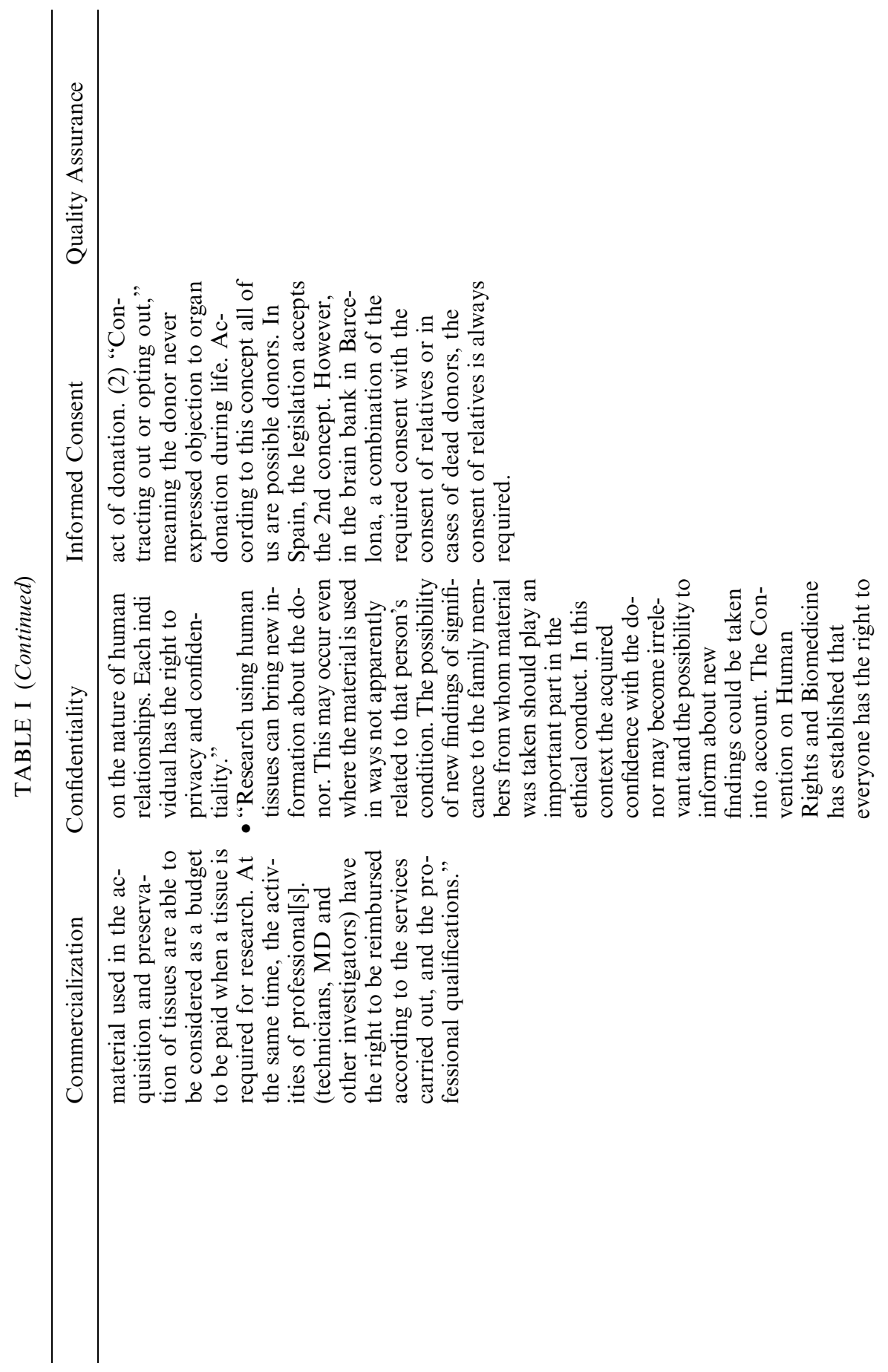




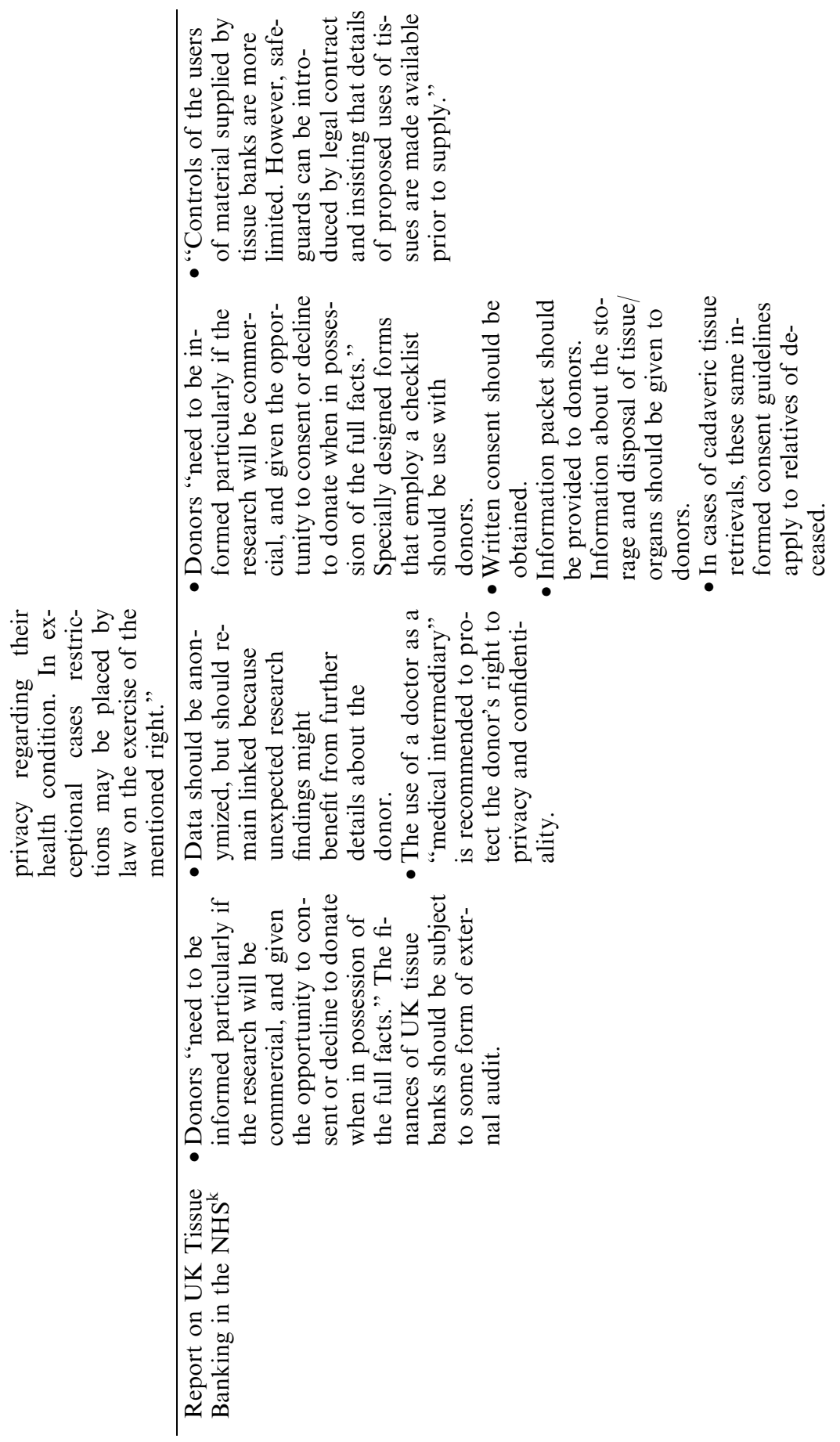




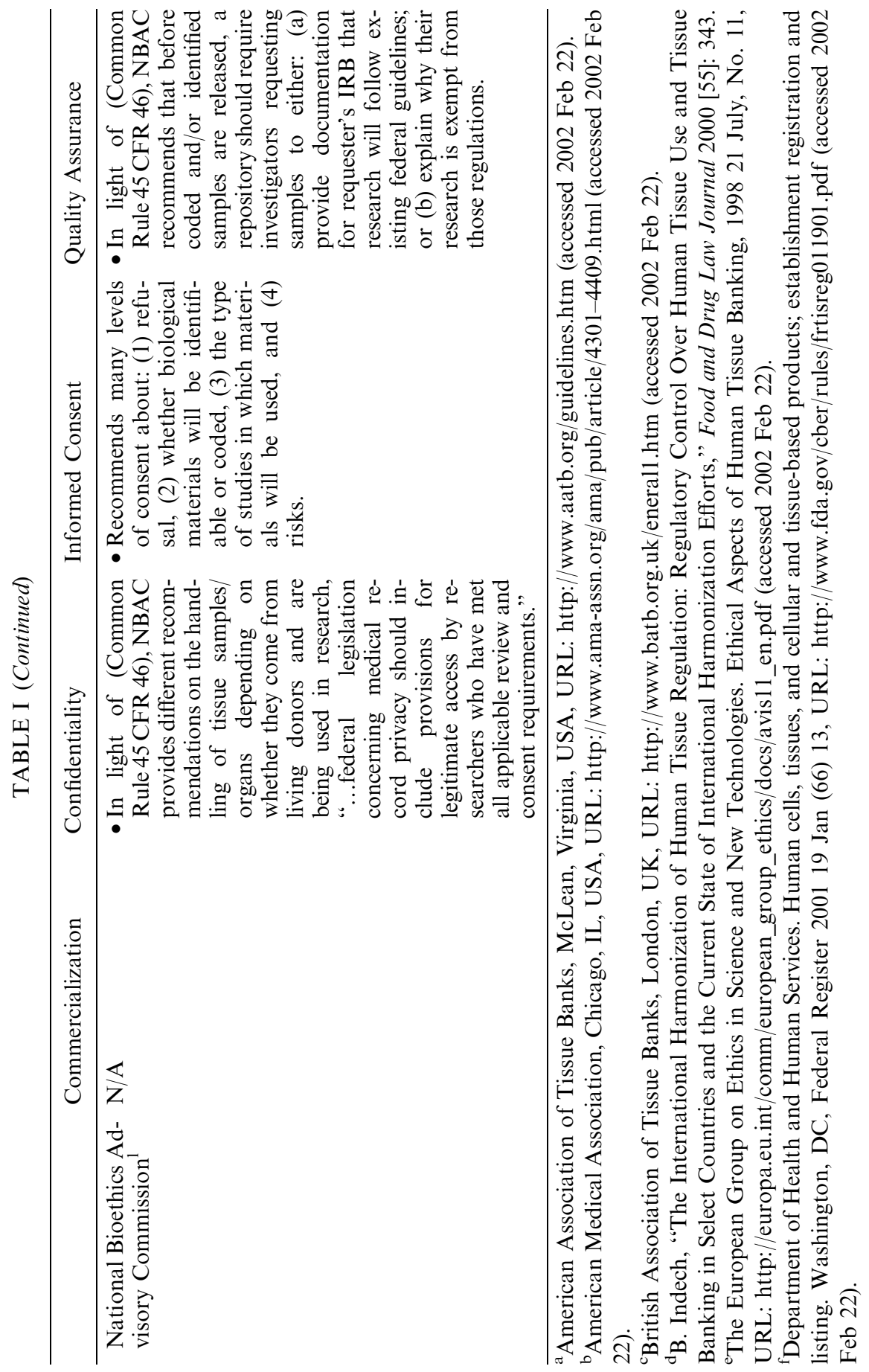




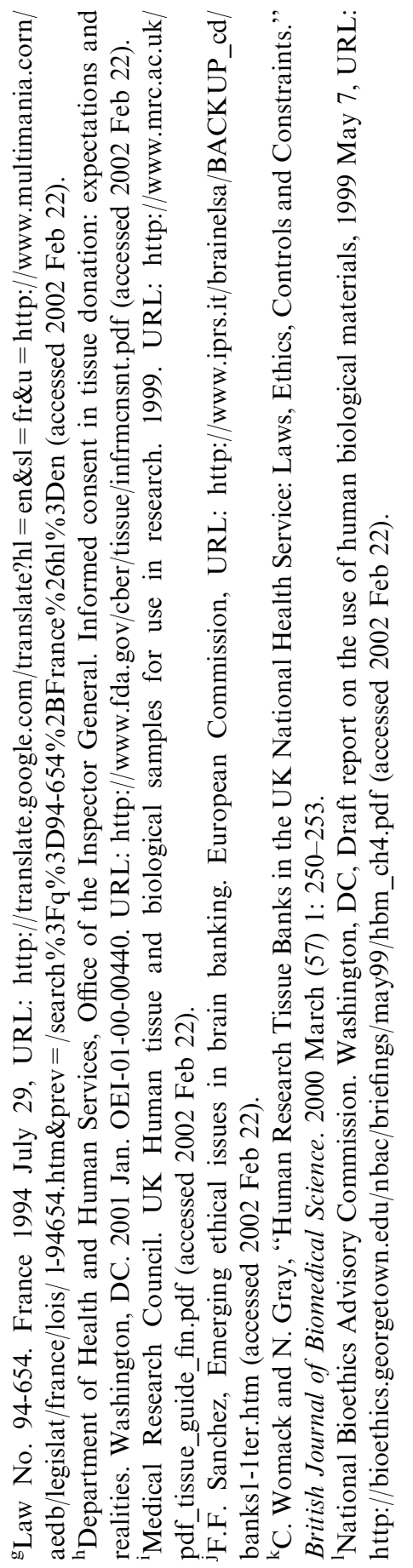


research and support the training of researchers. Perhaps the most important benefit associated with the commercialization of human tissue comes from the successful interchange between the two spheres, toward a more efficient transmission of knowledge from academicbased tissue banks to industry, facilitating the development and delivery of medical products to the public. ${ }^{7}$

There is, however, a potential downside to the commercialization of human tissues. Specifically, the growth of for-profit tissue banks and augmented academic-industry partnerships increase the likelihood of conflicts of interests. For example, financial incentives to academic researchers (e.g., stock options and royalties) could undermine scientific standards of integrity by promoting secrecy, data hoarding, and even the manipulation of research outcomes. If this occurs, the commercialization of human tissues could have the unintended consequence of compromising human tissue research and subordinating the health of the public to profit maximization.

Beyond concerns regarding conflicts of interests, the commercialization of human tissues also raises a host of broader social, cultural, religious, and psychological issues on the meanings we assign to the human body and, in particular, on how we treat it during life and after death. ${ }^{8}$ Many people conceptualize the transfer of human organs and tissues during life or after death as a gift motivated by altruistic feelings, not economic incentives. They believe that the buying and selling of human biological samples debases the value of human life, is antithetical to the gift paradigm of tissue transfer, can lead to further oppression of the disenfranchised and the poor, and is an affront to the dignity of donors and their families. Others, however, point out that the commodification of human tissues is not new ${ }^{9}$ (e.g., blood and sperm), and that "it is virtually impossible to imagine how human biological materials would be distributed if commerce in such materials were prohibited." "In fact, although U.S. federal law prohibits the buying and selling of human organs, it does allow fees for the recovering, processing and transporting of human tissue. ${ }^{11}$ The exportation of blood from the U.S. alone is a multi-billion dollar industry; ${ }^{12}$ other human tissues such as hair and corneas play an important role in commerce. Although the commodification of human tissue is not completely novel, the potential for much greater commercialization of human tissue does exist.

As illustrated in Table 1, the British Association of Tissue Banking (BATB), ${ }^{13}$ Belgium, ${ }^{14}$ and Spain ${ }^{15}$ have adopted policies and laws that simply ban all commercial dealings in human tissues. The BATB, 
for example, states "there shall be no commercial dealing in human tissue," the Spanish government holds that "the human body and its parts shall not, as such, give rise to financial gain" and, as specified in The Crown Order of June 13, 1986, the government of Belgium simply forbids the sale of body/body parts and profit from donation. The problem with this kind of approach is that it fails to specify what counts as a commercial activity and ignores or refuses to value the potential benefits of such activity. The American Association of Tissue Banks (AATB) ${ }^{16}$ provides even less guidance, as it has no explicit statement, general or specific, about the commercial aspects of tissue banking.

Unlike the BATB and the AATB, two reports from the Health and Human Services/Food and Drug Administration/Office of Inspector General (HHS/FDA/OIG) provide guidelines that address some of the commercial aspects of tissue banking. ${ }^{17}$ As illustrated in Table 1, these agencies hold the view that "the tissue banking industry should work with groups representing donor families to explore public disclosure of tissue banks' finances." Although these reports do not go as far as endorsing commercialization, they do recommend that donors/families be informed in a general way of the commercial uses of donated tissues and that tissue banks disclose their financing, as well as the industries with which they have financial arrangements.

Even if we grant that commercial academic-industry relationships are beneficial for spurring innovative research and providing healthcare services and products to the public, there remains the unresolved issue of whether donors and families should be financially compensated for donated tissues and for any profits that are generated by the research. The two HHS/FDA/OIG reports do not address this issue, but the policies developed by the European Commission (EC), the Medical Research Council (MRC), ${ }^{19}$ and France ${ }^{20}$ are explicit in their rejection of financial compensation and profit sharing with donors/families. There are two reasons why profit sharing with donors/families is rejected. One reason, according to the MRC, is that a donated body part or tissue sample is a "gift" and not a commodity for exchange in the marketplace. A second reason held by the EC, the MRC, and France is that the introduction of financial incentives could lead to the exploitation of donors/families. Overall, however, the EC, MRC, and France do allow for limited partnerships with industry. The MRC, for example, recommends that commercial companies receiving human tissues be allowed exclusive access to data for a period of time to secure patent protection and competitive 
advantage, whereas France recognizes that industry might at times have more resources to carry out highly technical human tissue research that will eventually benefit public health.

Still, all the policies but that of the AATB reflect an understanding of the most likely abuses associated with the commercialization of human tissue. The spectrum of positions on the commercialization of human tissues is represented in Table 2.

\section{CONFIDENTIALITY}

Confidentiality, which refers to the promise not to disclose information that the donor does not want disclosed, is treated by all the organizations and countries that were surveyed as an important value to be protected. Different levels exist among methods to curtail breaches of confidentiality. Commentators have outlined a useful taxonomy of:

- Identified: The tissue source is known and the individual's identity is tied to the sample.

- Identifiable: The tissue source is tied to the specimen through the use of a link (e.g., a code number), but the identity of the source is not directly known without tracing the link.

- Anonymized: The tissue source's identity is irrevocably unlinked from the specimen, so that the individual's identity cannot be discerned (i.e., the tissue is not identifiable).

- Anonymous: The tissue source's identity is never known, since the specimen is collected with no identifiers at all (i.e., the sample is unidentified). ${ }^{21}$

Anonymity is achieved when tissue made available for research will not have any personally identifiable links. This is one of the most effective ways to maintain confidentiality. However absolute confidentiality is nearly impossible to achieve in practice; nor is it always sought. Indeed, once tissue samples are anonymized, their potential uses in research are diminished - findings associated with tissue samples cannot be linked back to information regarding the samples' source of origin. On the other hand, linked specimens trigger the need for IRB review to make certain human subjects are adequately protected. ${ }^{22}$

The issue of whether tissues are stored as anonymized or identified specimens requires attention. If the tissue is identified, the question 


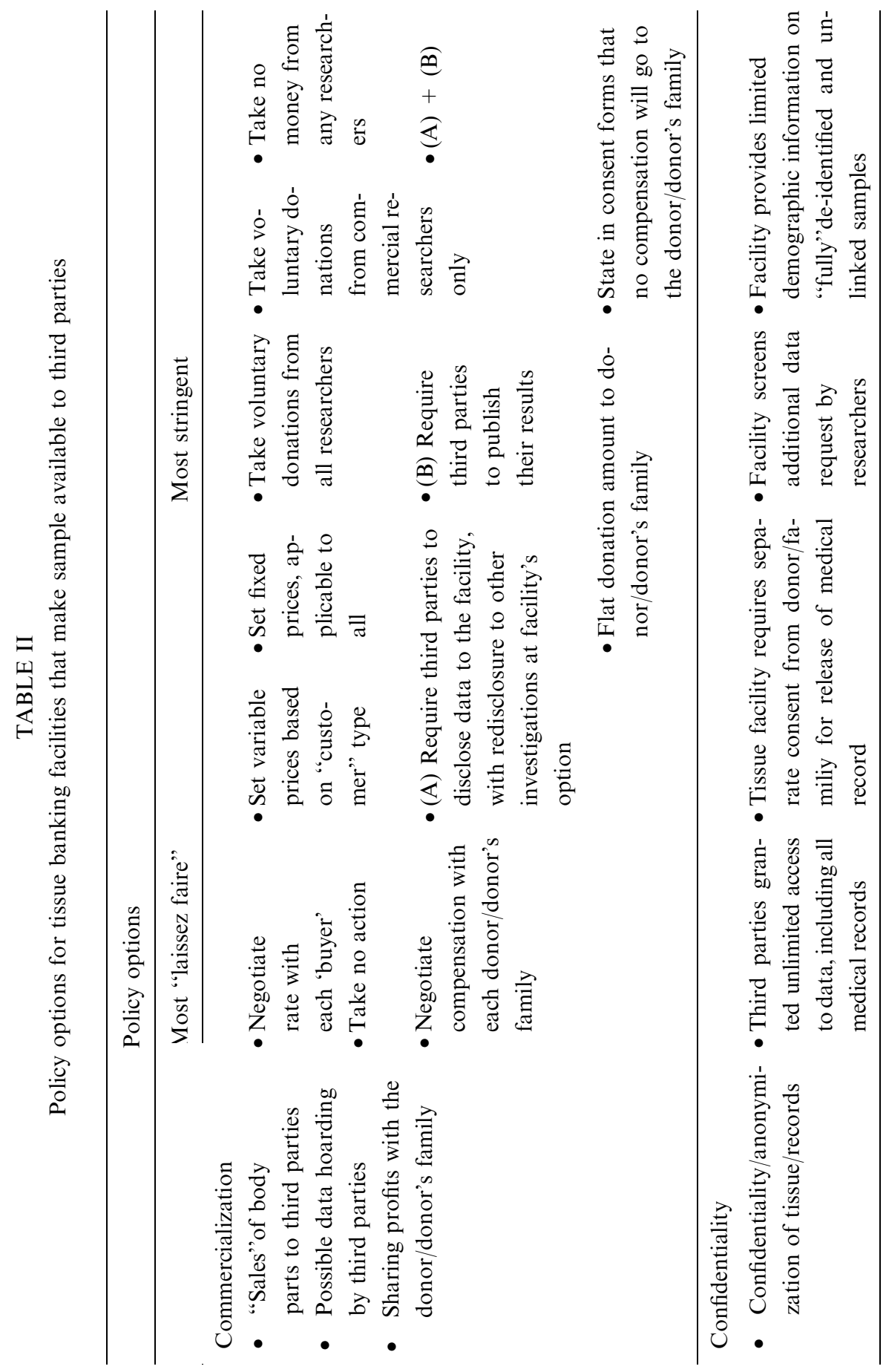




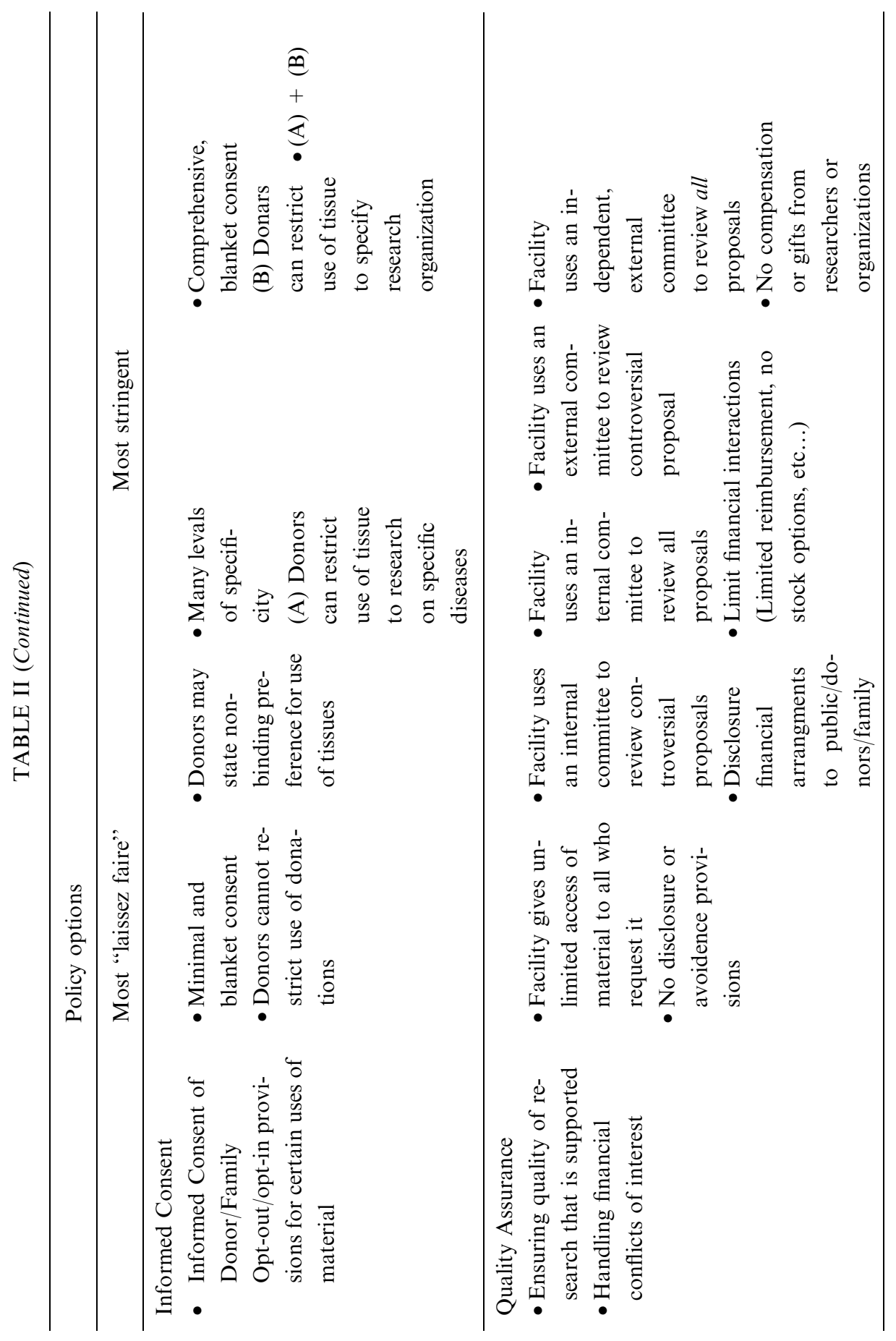


arises of whether researchers may access the donor's medical records. If this will be permitted, safeguards must be put into place to protect the donor's (or donor's family's) confidentiality, even prior to the informed consent process.

The BATB and the EC require coding systems that preserve both traceability and confidentiality. Within these policies, tissues are either identified or identifiable so that limited follow-up by authorized parties remains possible (if, for instance, a donor wanted to know about the possibility of commercial profitability). Unlike the BATB and EC, Spain has specific language that states, "the identity of the donor is not relevant to research purposes and is protected by the right to confidence." Other organizations, including the UK's MRC and the Report on UK Tissue Banking on NHS, use language such as "should" rather than "must" in requiring anonymization. ${ }^{23}$ Some US organizations have recently developed new policies that address adequate safeguards for maintaining confidentiality at the level of informed consent and beyond. For instance, the AMA's Code of Medical Ethics recommends that the level of privacy be disclosed to research subjects (i.e., whether the biological material will be coded or completely de-identified). ${ }^{24}$ Finally, the FDA has recently promulgated rules to regulate the tissue banking industry. All organizations that manufacture human cells, tissues, and cellular or tissue-based products will have to register and list their products with the FDA. Moreover, the new Health Insurance Portability and Accountability Act of 1996 (HIPAA) regulations in the US prohibit disclosures of "any protected health information related" to an individual's tissue samples. ${ }^{25}$ These new requirements will create the first comprehensive database of tissues banked in the US. The resulting database is likely to appeal to private and public entities for its research potential as well as commercial opportunities, as well as to raise future privacy concerns.

\section{INFORMED CONSENT}

Informed consent serves as a safeguard for individuals' rights and welfare, by providing them the opportunity to understand an intervention, its scope, and its implications, before they decide whether to agree to it. In the context of this discussion, the intervention is the collection of tissue samples by a tissue storage facility for the purpose of research. 
What should the informed consent process for the collection of tissue samples include? This question pertains to tissue samples that have yet to be collected. It needs to be distinguished from a related but separate matter: What should be done with collected tissue samples that were obtained with informed consent that would not meet current standards? The latter question is not directly addressed in this paper, which concerns itself with the collection of tissue, except to say that the more rigorous alternative of going back to donors or donors' families to obtain consent for unanticipated uses is the gold standard: it provides assurance that the donor's wishes will be respected. Unless donors (or their families) understand the specific nature of a research protocol in which they are enrolling, they neither can assess adequately whether participation in the overall investigation is consistent with their values, nor freely and deliberately refuse participation in certain aspects of a study.

For the reasons described above, minimal blanket consent, as reflected at one end of the spectrum in Table 2, is believed to be an inappropriate option for informed consent. ${ }^{26} \mathrm{~A}$ comprehensive blanket consent, which tries to anticipate in detail every possible use, present and future, of a tissue sample, may be overly burdensome and still may prove insufficient. The intermediary option offers a consent process that is tailored to the needs of the individual donor (or donor family) and to specific circumstances. The merit of the third option is that it is more flexible than the other two. However, all three policy alternatives for informed consent address the items discussed below.

\section{Collecting Tissue Samples: The Intervention}

Standards of informed consent require that the donor (or donor's family) have an adequate understanding of the procedure to retrieve tissue, including its risks and benefits. How the tissue will be removed, how much of it will be removed, and how the procedure will modify the appearance of the donor's body are among the questions that should be addressed, as well as any physical risks associated with the intervention in the case of a living donor.

\section{Collected Tissue Samples: Anticipated Uses}

Tissue storage facilities receive donations and make samples available to investigators for research purposes. The donor (or donor's family) may want to know whether the facility has ties with commercial, as 
well as non-commercial, companies. Does it stand to benefit financially? What criteria does the facility use to determine to whom to provide tissue samples? The party making the donation may be able to limit or suggest to what sort of company the samples should be provided. Along similar lines, the donor (or donor's family) might have the opportunity to specify or recommend toward what type of research the tissue may be used. The risk is that people with insufficient scientific grounding will participate in complex research decisions and that they may request limits that are difficult, unfeasible, or impossible to implement.

\section{Findings from Research on Tissue Samples}

It seems best to discuss at the time consent is sought what will later become of information derived from tissue samples. Two major questions arise with regard to findings. Should they be communicated to the donor (or donor's family)? It may be feasible for the facility to contact the donor (or donor's family) with findings that pertain to them, where the samples were identified. For this reason, it is important for potential donors to contemplate whether this is information they would welcome - and in what detail. Knowledge regarding the risks and benefits associated with learning this sort of information - and what it means that it is familial in nature - can help inform this decision. Where tissue samples are anonymized, general findings are the only kind of information the donor (or the donor's family) can consent to receive.

The other question that arises from the findings is whether the donor (or donor's family) can share in any profits from products, tests, or discoveries that result from the research. While it seems easiest to preclude this sort of sharing, some organizations allow it. Details of how the donor (or the donor's family) will benefit are worked out during the consent process. In these latter cases, it is helpful to determine conditions as part of the informed consent process.

While the organizational policies that were reviewed all include a discussion of consent, they reflect a broad range of standards. Several of the European policies rely on notions of presumed consent for organ and tissue retrieval from deceased individuals (Belgium, European Commission, France, and Spain), while British and American policies stress informed consent with different levels of specificity. 
TABLE III

Definitions of key terms

\begin{tabular}{|c|c|}
\hline Key terms & Definitions \\
\hline Human tissue & $\begin{array}{l}\text { Includes everything from organs and parts of organs, cells and } \\
\text { tissues to subcellular structures and cell products, blood, } \\
\text { gametes, embryos and fetal tissue, and waste. Also referred to } \\
\text { as "human biological material." }\end{array}$ \\
\hline Renewable tissue & $\begin{array}{l}\text { Renewable tissue refers to tissue that the body produces and } \\
\text { replenishes on a regular basis. Such tissue includes hair, nails, } \\
\text { gametes and skin. }\end{array}$ \\
\hline $\begin{array}{l}\text { Non-renewable } \\
\text { tissue }\end{array}$ & $\begin{array}{l}\text { Non-renewable tissue refers to tissue and organs that the body } \\
\text { does not replenish. Such tissues and organs include internal } \\
\text { organs such as liver and kidneys as well as corneas. }\end{array}$ \\
\hline Tissue banking & $\begin{array}{l}\text { Tissue banking is the storage of tissue. Tissue is stored for } \\
\text { diagnostic procedures, surgical treatment, as well as educa- } \\
\text { tional and research purposes. }\end{array}$ \\
\hline Tissue storage & $\begin{array}{l}\text { Tissue is stored in military facilities, forensic DNA banks, } \\
\text { government laboratories, diagnostic pathology and cytology } \\
\text { laboratories, university- and hospital-based research labora- } \\
\text { tories, commercial enterprises, and nonprofit organizations. }\end{array}$ \\
\hline
\end{tabular}

${ }^{\mathrm{a} C \text { C. Naser and S. Alpert, "Genetic Information, Ethics, Ethical Issues in Tissue }}$ Banking and Human Subject Research in Stored Tissues," in Encyclopedia of Ethical, Legal, and Policy Issues in Biotechnology, eds. T.H. Murray and M.J. Mehlman (New York: Jon Wiley \& Sons, 2000), pp. 363-369.

\section{QUALITY OF RESEARCH}

Tissue donors might well assume that their tissues will be used only to further research that is of the highest possible quality. But tissues are frequently in greater demand than banks can supply, so allocation decisions must be made. In this process, the presumption that only the highest quality research projects will receive tissues may be subverted by both organizational and personal conflicts of interest. Financial conflicts of interest pose immediate concerns. For example, if providing tissues to commercial researchers promises greater financial rewards for the tissue bank, or its staff, there may be a temptation to provide tissue to these researchers even at the expense of other, higher quality, research proposals from non-commercial sites. But not all potentially conflicting interests are financial. Re- 
search that is of particular interest to the bankers may receive special consideration, which may or may not be appropriate. A bank established to promote research in Alzheimer's disease will rightfully give priority to projects that directly address this condition, but would it be appropriate for the director of the bank to refuse to provide tissues to researchers in areas that compete with his or her own research?

To avoid the perception, or reality, of poorer quality research taking precedence over higher quality research for financial or other inappropriate reasons, tissue banks can attend to issues such as who makes allocation decisions, using what criteria, and under what checks and balances, with greater transparency. Unfortunately, these issues were directly addressed in only five of the documents we examined (AATB, BATB, HHS/OIG, Womack and Gray). Even these policies tended towards broad statements about preventing discrimination, maximizing research benefits, avoiding financial conflicts of interest, and ensuring that recipient scientists are trained in the proper handling and use of donated tissues.

\section{DISCUSSION}

In light of our examination of representative tissue banking policies, we believe that tissue banks systematically should consider the following requirements:

First, each tissue bank should have a mission statement, against which it can assess the merits of proposed uses of donated tissue. Developing such a document will serve to provide a definition of what constitutes high quality research in the eyes of the particular bank.

Second, financial conflicts of interest can be addressed, in part, by ensuring that those making tissue allocation decisions do not have personal financial stakes in potential recipient organizations, or by sharply circumscribing such relationships. Table 1 lists a few of the ways in which organizations have proposed limiting financial interactions between tissue banks, their officers and staff, and commercial or non-commercial enterprises. Except in the smallest of organizations or where no shortage of tissues exists, no single person should have control over allocation decisions. At minimum, there should be written criteria for evaluating proposed research projects; at best, there will be a clearly defined process for reviewing and approving the 
use of donated tissues, which will fall along the continuum outlined in Table 2.

Third, tissue banks should be explicit about their standards of "confidentiality:" Are tissues identified, identifiable, anonymized, or anonymous? They should develop adequate methods to limit breaches of confidentiality, which are made known. Tissue banking guidelines and policies need be specific about the conditions under which donated tissues will be deemed confidential. By doing so, tissue banking guidelines will be more effective in minimizing potential harms to donors, donor families, as well as to future tissue research and product development.

Fourth, tissue banking guidelines and policies should specify what information to address as part of the informed consent process. To do this, tissue banks will already need to be clear about their mission, financial arrangements, and level of confidentiality protections they intend to use. It is only after receiving the required information that the donor (or donor's family) can arrive at an informed decision about whether to provide tissue samples to the facility. Toward this goal, the information to be addressed should be presented in clear and understandable language.

These four main requirements are meant to offer general guidance regarding ethical considerations that deserve to be examined. They are neither exhaustive, nor absolute. Rather, they relate to the four factors (commercialization, confidentiality, informed consent, and quality of research) that emerged from the authors' review. Institutional Review Boards, or corresponding bodies, the purview of which is to ensure the protection of research participants, must be involved to aid tissue banks by providing appropriate oversight and monitoring of their activities that relate to research, as well as assistance with specific ethical issues as they arise.

\section{CONCLUSION}

Some organizational policies do not address commercialization, while others fail to consider confidentiality and quality of research. However, even in those instances where one of the four factors is recognized by all policies (commercialization, confidentiality, informed consent, and quality of research), there is often a lack of uniformity in its meaning, scope, and ethical significance. Until uniform ethical guidelines regulating the storage, distribution, and use of human 
tissues for research are established, the international transfer of human tissues and multinational research involving industry will not only remain cumbersome but, in many instances, ethically problematic. We propose that governments, non-governmental organizations, and other institutions further collaborate and harmonize policies regarding human tissue, keeping in mind the four factors we outline here.

\section{ACKNOWLEDGEMENTS}

We thank Matthew Wynia, MD, MPH for suggesting the idea behind this article and for providing some conceptual foundations during its early development. We also thank Elisa Gordon, PhD, Erin Egan, MD, JD, and Robert Mittendorf, MD, DrPh, for their comments and suggestions.

\section{NOTES}

1 Deborah Josefson, "Human Tissue for Sale: What Are the Costs?" Western Journal of Medicine 5 (2000): 302-303.

2 Ted T. Ashburn, Sharon K. Wilson, Barry I. Eisenstein, "Human Tissue Research in the Genomic Era of Medicine: Balancing Individual and Societal Interests," $A r$ chives of Internal Medicine 160 (2000): 3377-3384. See also, generally, Robert F. Weir, ed., Stored Tissue Samples: Ethical, Legal, and Public Policy Implications (Iowa City: University of Iowa Press, 1998).

3 See Table 3 for a list of definitions regarding human tissue. For the purposes of this paper, we generally exclude organs from the definition of tissue. Moreover, "donor" in this paper means both living and deceased individuals.

4 Joseph B. Martin, Dennis L. Kasper, "In Whose Best Interest? Breaching the Academic-Industrial Wall," New England Journal of Medicine 343 (2000): 16461649.

5 Deborah Josefson, "US Hospitals to Ask Patients for Right to Sell their Tissue," British Medical Journal 321 (2000): 653.

${ }^{6}$ The authors identified these four factors in the early stages of their research, when considering whether and under what conditions non-profit academic brain tissue repositories should provide for-profit private companies with brain tissue samples of deceased individuals.

7 John P. Swan, Academic Scientist and the Pharmaceutical Industry (Baltimore: The John Hopkins University Press, 1988).

8 Dorothy Nelkin, Lori Andrews, "Homo Economicus: Commercialization of Body Tissue in the Age of Biotechnology," Hastings Center Report 28 (1998): 30-39.

9 Linda F. Hogle, Recovering the Nation's Body: Cultural Memory, Medicine, and the Politics of Redemption (New Brunswick, NJ: Rutgers University Press, 1999): 24. 
${ }^{10}$ Julia D. Mahoney, "The Market for Human Tissue," Virginia Law Review March, 86 (2000): 163-223.

${ }^{11}$ National Organ Transplant Act, 1984. Pub L. No. 98-507, 3 USC *301.

${ }^{12}$ Danielle M. Wagner, "Property Rights in the Human Body: The Commercialization of Organ Transplantation and Biotechnology," Duquesne Law Review, 33 (1995): 931-958.

${ }^{13}$ British Association of Tissue Banking, "General Standards for Tissue Banking," (Sept 29, 1999). Available at: http://www.batb.org.uk/generall.htm.

${ }^{14}$ Barbara Indech, "The International Harmonization of Human Tissue Regulation: Regulatory Control over Human Tissue Use and Tissue Banking in Select Countries and the Current State of International Harmonization Efforts," Food and Law Journal, 55 (2000): 343-372.

${ }^{15}$ F.F. Cruz-Sanchez, "Emerging Ethical Issues in Brain Banking," European Commission financed Ethical, Legal, and Social Aspects of Brain Research (1997). Available at: http://www.iprs.it/brainelsa/BACKUP_cd/banks1-1ter.htm.

${ }^{16}$ American Association of Tissue Banks, "Ethical Guidelines for Commercial Activities and Advertising," (Sept. 11, 1996). Available at: http://www.aatb.org/ guidelines.htm.

${ }^{17}$ Department of Health and Human Services, "Human Cells, Tissues, and Cellular and Tissue-Based Products; Establishment Registration and Listing," Federal Register 66 (Jan. 19, 2001): Rules and Regulations. Available at: http://www.fda.gov/ cber/rules/frtisreg011901.pdf.

${ }^{18}$ European Group on Ethics in Science and New Technologies to the European Commission, "Ethical Aspects of Human Tissue Banking," 11 (July 21, 1998). Available at: http://europa.eu.int/comm/european_group_ethics/docs/avis11_en. pdf.

${ }^{19}$ Medical Research Council Working Group to Develop Operational and Ethical Guidelines, "Human Tissue and Biological Samples for Use in Research," (April 2001). Available at: http://www.mrc.ac.uk/pdf-tissue_guide_fin.pdf.

${ }^{20}$ See note 15 , above.

${ }^{21}$ Curtis Naser and Sheri Alpert, "Genetic Information, Ethics, Ethical Issues in Tissue Banking and Human Subject Research in Stored Tissues," in: Encyclopedia of Ethical, Legal, and Policy Issues in Biotechnology, eds. T.H. Murray and M.J. Mehlman (New York: John Wiley \& Sons, 2000), p. 365.

${ }^{22}$ Naser, Alpert cited in n. 21, above, p. 367.

${ }^{23}$ Christopher Womack, Neil Gray, "Human Research Tissue Banks in the UK National Health Service: Law, Ethics, Controls and Constraints," British Journal of Biomedical Science 55 (2000): 250-253.

24 "Opinion 2.079: Safeguards in the Use of DNA Databanks in Genomic Research," in Council on Ethical and Judicial Affairs, American Medical Association, Code of Medical Ethics: Current Opinions with Annotations (Chicago, IL: AMA Press, 2002).

${ }^{25}$ Department of Health and Human Services, Office of the Secretary, "Standards for Privacy of Individually Identifiable Health Information," 45 CFR Parts 160 through 164. See http://www.cms.hhs.gov/hipaa/hipaa2/regulations/privacy/finalrule/PvcTxt01.asp. 
${ }^{26}$ Henry T. Greely, "Breaking the Stalemate: A Regulating Framework for Unforeseen Research Uses of Human Tissue Samples and Health Information," Wake Forest Law Review, 34 (1999): 737-766.

\section{REFERENCES}

American Association of Tissue Banks. "Ethical Guidelines for Commercial Activities and Advertising." (September 11, 1996). Available at: http://www.aatb.org/ guidelines.htm.

Ashburn, T.T., S.K. Wilson, and B.I. Eisenstein. "Human Tissue Research in the Genomic Era of Medicine: Balancing Individual and Societal Interests." $A r$ chives of Internal Medicine 160 (2000): 3377-3384.

British Association of Tissue Banking. "General Standards for Tissue Banking." (September 29, 1999). Available at: http://www.batb.org.uk/generall.htm.

Council on Ethical and Judicial Affairs, American Medical Association. Code of Medical Ethics: Current Opinions with Annotations. Chicago, IL: AMA Press, 2002.

Cruz-Sanchez, F.F. "Emerging Ethical Issues in Brain Banking." European Commission financed Ethical, Legal, and Social Aspects of Brain Research, 1997. Available at: http://www.iprs.it/brainelsa/BACKUP_cd/banks1-1ter.htm.

Department of Health and Human Services, Office of the Secretary. "Standards for Privacy of Individually Identifiable Health Information." 45 CFR Parts 160 through 164. Available at: http://www.cms.hhs.gov/hipaa/hipaa2/regulations/ privacy/finalrule/PvcTxt01.asp.

Department of Health and Human Services. "Human Cells, Tissues, and Cellular and Tissue-Based Products; Establishment Registration and Listing." Federal Register 66 (January 19, 2001): Rules and Regulations. Available at: http:// www.fda.gov/cber/rules/frtisreg011901.pdf.

European Group on Ethics in Science and New Technologies to the European Commission. "Ethical Aspects of Human Tissue Banking." 11 (July 21, 1998). Available at: http://europa.eu.int/comm/european_group_ethics/docs/avis11_en.pdf.

Greely, H.T. "Breaking the Stalemate: A Regulating Framework for Unforeseen Research Uses of Human Tissue Samples and Health Information." Wake Forest Law Review 34 (1999): 737-766.

Hogle, L.F. Recovering the Nation's Body: Cultural Memory, Medicine, and the Politics of Redemption. New Brunswick, NJ: Rutgers University Press, 1999.

Indech, B. "The International Harmonization of Human Tissue Regulation: Regulatory Control over Human Tissue Use and Tissue Banking in Select Countries and the Current State of International Harmonization Efforts." Food and Law Journal 55 (2000): 343-372.

Josefson, D. "Human Tissue for Sale: What Are the Costs?" Western Journal of Medicine 5 (2000): 302-303.

Josefson, D. "US Hospitals to Ask Patients for Right to Sell Their Tissue." British Medical Journal 321 (2000): 653.

Mahoney, J.D. “The Market for Human Tissue.” Virginia Law Review 86 (2000): $163-223$ 
Martin, J.B., and D.L. Kasper. "In Whose Best Interest? Breaching the AcademicIndustrial Wall." New England Journal of Medicine 343 (2000): 1646-1649.

Medical Research Council Working Group to Develop Operational and Ethical Guidelines. "Human Tissue and Biological Samples for Use in Research." (April 2001). Available at: http://www.mrc.ac.uk/pdf-tissue_guide_fin.pdf.

Murray, T.H., and M.J. Mehlman, eds. Encyclopedia of Ethical, Legal, and Policy Issues in Biotechnology. New York: John Wiley and Sons, 2000.

National Organ Transplant Act, 1984. Pub L. No. 98-507, 3 USC *301.

Nelkin, D., and L. Andrews. "Homo Economicus: Commercialization of Body Tissue in the Age of Biotechnology." Hastings Center Report 28 (1998): 30-39.

Swan, J.P. Academic Scientist and the Pharmaceutical Industry. Baltimore: The John Hopkins University Press, 1988.

Wagner, D. "Property Rights in the Human Body: The Commercialization of Organ Transplantation and Biotechnology." Duquesne Law Review 33 (1995): 931-958.

Weir, R.F., ed. Stored Tissue Samples: Ethical, Legal, and Public Policy Implications. Iowa City: University of Iowa Press, 1998.

Womack, C., and N. Gray. "Human Research Tissue Banks in the UK National Health Service: Law, Ethics, Controls and Constraints." British Journal of Biomedical Science 55 (2000): 250-253.

KEITH BAUER

Department of Philosophy

Marquette University

U.S.A

SARA TAUB

Ethics Standards Group

American Medical Association

Chicago, IL

U.S.A

E-mail:sara_taub@ama-assn.org

\section{KAYHAN PARSI}

Neiswanger Institute for Bioethics and Health Policy

Stritch School of Medicine

Loyola University Chicago

U.S.A 